Tohoku J. Exp. Med., 2010, 221, 35-42

\title{
Polymorphisms in the Surfactant Protein A Gene Are Associated with the Susceptibility to Recurrent Urinary Tract Infection in Chinese Women
}

\author{
Jiao Liu, ${ }^{1}$ Fengqi Hu, ${ }^{1}$ Wei Liang, ${ }^{1}$ Guirong Wang, ${ }^{2}$ Pravin C. Singhal ${ }^{3}$ and \\ Guohua Ding ${ }^{1}$ \\ ${ }^{1}$ Department of Medicine, Renmin Hospital of Wuhan University, Wuhan, Hubei, China \\ ${ }^{2}$ Department of Pediatrics, The Pennsylvania State University College of Medicine, Hershey, PA, USA \\ ${ }^{3}$ Department of Medicine, Long Island Jewish Medical Center, New Hyde Park, NY, USA
}

\begin{abstract}
Some risk factors for susceptibility to recurrent urinary tract infection (r-UTI) are well known, but the genetic role in acquiring the disease is poorly understood. Surfactant protein A and D (SP-A and SP-D) play an important role in modulation of lung inflammatory processes. The SP-A1 and SP-A2 genes encoding SP-A and the SP-D gene are highly polymorphic, and some of polymorphisms are associated with several infective diseases, including pyelonephritis. In the present study, we investigated whether some of these polymorphisms are associated with the risk of r-UTI in Chinese population. Genomic DNA was extracted from blood samples of 32 female patients with r-UTI and 30 age-matched, unrelated healthy female subjects. Genotyping of gene polymorphisms was analyzed by PCR. Among 11 single nucleotide polymorphisms (SNPs) (five of SP-A1, four of SP-A2 and two of SP-D) observed in the enrolled subjects, Ala19Val of SP-A1 and Lys223GIn of SP-A2 were associated with susceptibility to $\mathrm{r}$-UTI. The frequencies of 19Ala allele of SP-A1 gene $(p=0.038)$ and 223Gln allele of SP-A2 gene $(p=0.012)$ in the patients were significantly higher than those in healthy subjects. The serum SP-A and SP-D levels were increased and the urine SP-A and SP-D levels were decreased in r-UTI patients compared with control subjects $(p<0.05)$. $\mathrm{r}$-UTI patients with 19Ala/Ala or $223 \mathrm{Gln} / \mathrm{Gln}$ genotype were associated with high serum and low urine SP-A levels $(p<0.01)$. Therefore, the 19Ala allele of SP-A1 gene and the 223Gln allele of SP-A2 gene are risk factors for $r$-UTI.
\end{abstract}

Keywords: recurrent urinary tract infection; surfactant protein A; surfactant protein D; single nucleotide polymorphism; Chinese women

Tohoku J. Exp. Med., 2010, 221 (1), 35-42. (C) 2010 Tohoku University Medical Press

Recurrent urinary tract infection (r-UTI) remains one of the common infections affecting adult female. Almost $27 \%$ of women developed a recurrent UTI within the 6 months (Foxman 1990) and nearly 50\% of women developed a recurrence within the first year following the initial infection (Mabeck 1972). Clinical studies showed that only a fraction of r-UTI patients had obvious functional, anatomic and behavioral risk factors, which were considered to be strongly associated with an increased risk of r-UTI. Recently, genetic studies have reported the associations of polymorphisms within innate immune molecules such as Toll-like receptor 2 and 4 (TLR2 and TLR4) with r-UTI susceptibility (Karoly et al. 2007; Lundstedt et al. 2007; Tabel et al. 2007; Hawn et al. 2009). The host genetic factor has been considered as one of the pathogenesis of r-UTI. However, the specific genes involved remained largely unknown.
Surfactant protein A and D (SP-A and SP-D), which are expressed and secreted by alveolar type II cells (Walker et al. 1986), could keep pulmonary alveoli from collapsing at the end of expiration (King and Clements 1972). In addition to their roles in surfactant homeostasis, SP-A and SP-D can participate in innate immune response and inflammatory processes (LeVine et al. 2000). The involvement of them in inflammatory reactions have been supported by the following observations: The SP-A or SP-D knockout mice exhibited increased levels of pro-inflammatory cytokines and decreased ability of phagocytosis by alveolar macrophages (LeVine et al. 2000; Linke et al. 2001). In our previous work, we have demonstrated that SP-A expression correlated with degree of inflammation in kidneys of pyelonephritic rats (Tian et al. 2005).

Human SP-A and SP-D genes are located on the chromosome 10q22-q23 (Kölble et al. 1993). SP-A consists of

Received February 12, 2010; revision accepted for publication March 22, 2010. doi:10.1620/tjem.221.35

Correspondence: Guohua Ding, M.D., Ph.D., Division of Nephrology, Renmin Hospital of Wuhan University, Wuhan, Hubei 430060, China.

e-mail: ghxding@gmail.com 
one SP-A1 and two SP-A2 molecules forming a trimer (Karinch et al. 1997). SP-A1 and SP-A2 share 96\% similarity in amino acid sequence and $97 \%$ similarity in nucleotide sequence. Almost 10 genetic variants (alleles) of SP-A1 and SP-A2 have more than $1 \%$ frequency in general population. The SP-A1 alleles differ at codons for amino acids residue 19(Ala19Val), 50(Leu50Val), 62(Pro62Pro), 133(Thr133Thr), 219(Arg219Trp) and the SP-A2 alleles at 4 codons, encoding amino acids residue 9(Thr9Asn), 91(Pro91Ala), 140(Ser140Ser), and 223(Lys223Gln). Though there are only nearly 10 amino acid differences in SP-A1 and SP-A2 allele products, the SP-A2 allele gene products exhibit a more significant effect in biochemical functions than SP-A1 allele gene products (DiAngelo et al. 1999; Wang et al. 2000; Wang et al. 2004; Mikerov et al. 2007). Two polymorphisms within SP-D gene have been identified in the exonic sequence: codons corresponding to amino acid residue 11 (Thr11Met), 160(Thr160Ala) (DiAngelo et al. 1999; Pantelidis et al. 2003). Among the single nucleotide polymorphisms (SNPs) of SP-A1, SP-A2 and SP-D, most of them are missense mutations, except for the Pro62Pro and Thr133Thr polymorphisms of SP-A1 gene and the Ser140Ser polymorphism of SP-A2 gene.

The genetic variations of SP-A1, SP-A2 and SP-D genes have been reported to be related with susceptibility to high-altitude pulmonary edema, allergic bronchopulmonary aspergillosis and respiratory syncytial virus infection (Saxena et al. 2005; Vaid et al. 2007; Thomas et al. 2009). However, there is no report indicating the association of SP-A1, SP-A2 and SP-D gene polymorphisms with urinary tract infection. In the present study, we focused on genetic variants in the exonic regions of SP-A1, SP-A2 and SP-D genes in order to see if these polymorphisms contributed to the r-UTI susceptibility in Chinese population; moreover, we examined whether genetic variants affected their protein levels in serum and urine.

\section{Materials and Methods}

\section{Human subjects}

Thirty-two non-pregnant women with r-UTI (aged 18-70 yrs) and thirty age-matched healthy women (aged 18-70 yrs, control) were included in the present study. All subjects were recruited from the Division of Nephrology at the Renmin Hospital of Wuhan University from May 2008 to March 2009. The study procedure was carried out according to the protocol approved by the human ethics committee of the Renmin Hospital of Wuhan University in China.

\section{Diagnostic criteria}

All the patients had $\geq 3$ recurrences of UTI per year or $\geq 2$ recurrences of UTI within 6 months. Urine analysis revealed bacterial counts $\geq 10^{5}$ per $\mathrm{ml}$ or $\geq 25 \mathrm{WBC} / \mu 1$ in a freshly voided midstream urine sample. Exclusion criteria included the patients with anatomical and functional urinary tract abnormalities, such as urinary tract obstruction due to calculi or any other causes, continuous or intermittent urethral catheterization, or post-voidal residual urine volume $>100 \mathrm{ml}$. In addition, patients with urological neoplasms, vesicoureteral reflux (VUR), systemic lupus erythematosus, and diabetes were also excluded.

Genomic DNA extraction and genotyping analysis

All the peripheral blood samples were stored at $-70^{\circ} \mathrm{C}$. Genomic DNA was extracted from peripheral blood mononuclear cells (PBMCs) using a Kit (Solarbio, China) according to the instructions provided by the manufacturer. The final concentrations of genomic DNA, determined by ultraviolet spectroscopical luminosity, were about $0.06-0.12 \mu \mathrm{g} / \mu \mathrm{l}$. Using genomic DNA as templates, SNPs of SP-A1 gene (Ala19Val, Leu50Val, Pro62Pro, Thr133Thr and Arg219Trp), SP-A2 gene (Thr9Asn, Pro91Ala, Ser140Ser and Lys223Gln), and SP-D gene (Thr11Met and Thr160Ala) were analyzed by sequence specific primer-polymerase chain reaction (PCRSSP) as described by Pantelidis et al. (2003). The primers were shown in Table 1. This method provided the reproducible results for all the SNP loci with modifications in annealing temperature as the following: initial denaturation $1 \mathrm{~min}$ at $94^{\circ} \mathrm{C}$; followed by 5 cycles of $20 \mathrm{~s}$ at $94^{\circ} \mathrm{C}, 45 \mathrm{~s}$ at $\mathrm{T}_{\mathrm{m} 1}, 25 \mathrm{~s}$ at $72^{\circ} \mathrm{C} ; 21$ cycles of $25 \mathrm{~s}$ at $94^{\circ} \mathrm{C}, 50 \mathrm{~s}$ at $\mathrm{T}_{\mathrm{m} 2}, 30 \mathrm{~s}$ at $72^{\circ} \mathrm{C} ; 4$ cycles of $30 \mathrm{~s}$ at $94^{\circ} \mathrm{C}, 60 \mathrm{~s}$ at $\mathrm{T}_{\mathrm{m} 3}, 120 \mathrm{~s}$ at $72^{\circ} \mathrm{C}$; then additionally at $72^{\circ} \mathrm{C}$ for $3 \mathrm{~min}$. The Ala19Val, Leu50Val polymorphisms of SP-A1 gene and the Thr160Ala polymorphism of SP-D gene shared the same annealing temperature $70^{\circ} \mathrm{C}-65^{\circ} \mathrm{C}$ $55^{\circ} \mathrm{C}\left(\mathrm{T}_{\mathrm{m} 1}-\mathrm{T}_{\mathrm{m} 2}-\mathrm{T}_{\mathrm{m} 3}\right)$; the Pro62Pro, Thr133Thr, Arg219Trp polymorphisms of SP-A1 gene and the Ser140Ser, Lys223Gln polymorphisms of SP-A2 shared the same annealing temperature $70^{\circ} \mathrm{C}-65^{\circ} \mathrm{C}$ $58^{\circ} \mathrm{C}\left(\mathrm{T}_{\mathrm{m} 1}-\mathrm{T}_{\mathrm{m} 2}-\mathrm{T}_{\mathrm{m} 3}\right)$; while the Thr9Asn, Pro91Ala polymorphisms of SP-A2 and the Thr11Met polymorphism of SP-D gene shared the same annealing temperature $65^{\circ} \mathrm{C}-55^{\circ} \mathrm{C}-50^{\circ} \mathrm{C}\left(\mathrm{T}_{\mathrm{m} 1}-\mathrm{T}_{\mathrm{m} 2}-\mathrm{T}_{\mathrm{m} 3}\right)$. The PCR products were subjected to separation by electrophoresis on $2 \%$ agarose gel.

\section{Measurement of serum and urine SP-A and SP-D concentrations}

Urine and blood samples were centrifugated, and the supernatants were collected for the measurement of serum and urine SP-A and SP-D by enzyme-linked immunosorbent assay (ELISA) using the human SP-A and SP-D ELISA kit (ADL, American).

\section{Statistical analysis}

Statistical analysis was performed by SPSS 11.5 software. Hardy-Weinberg equilibrium (HWE) was used to determine whether the genotypes and allele frequencies were consistent with gene genetic balance. Student's $T$ test was used for comparison of quantitative variables. Allele and genotype frequencies in patients with r-UTI and health control subjects were compared using row $\times$ column tables, $2 \times$ 2 tables and Fisher exact tests (for sample number $<5$ in a group). The $\chi^{2}$ were calculated. When $p$ value was less than 0.05 , it was considered as statistically significant.

\section{Results}

\section{Clinical characteristics of $r$-UTI patients}

r-UTI subjects were identified based on three clinical recurrences within a year or two recurrences within 6 months. Urine analysis showed that the bacterial counts were $\geq 10^{5}$ per $\mathrm{ml}$ or $25 \mathrm{WBC} / \mu 1$ in a freshly voided midstream urine sample. The average ages of $\mathrm{r}$-UTI patients and control subjects were $40.59 \pm 11.38$ years and $39.73 \pm$ 13.30 years, respectively. In thirty-two r-UTI patients, fifteen suffered from lumbar pain, three complained of gross 
Table 1. The primer sequences and the gene locations.

\begin{tabular}{|c|c|c|}
\hline Primer & Location & Sequences $5,-3$, \\
\hline SPA1-19Val & $120149-120129[\mathrm{Ex} 1]$ & AAACGTCCTTCACTTCGCACA \\
\hline SPA1-19Ala & $120148-120129[\mathrm{Ex} 1]$ & AACGTCCTTCACTTCGCACG \\
\hline SPA1-50Leu & $120238-120221[\mathrm{Ex} 1]$ & GCCAGGGTCTCCTTTGAG \\
\hline SPA1-50Val & 120238-120221 [Ex1] & GCCAGGGTCTCCTTTGAC \\
\hline Consensus-19 & 119633-119654 [Prom] & AGTGAGTGAGTGACCTGACTAA \\
\hline SPA1-62Pro(A) & 120592-120573 [Ex2] & GACATGGCATTTCTCCAGGT \\
\hline SPA1-62Pro(G) & 120592-120573 [Ex2] & GACATGGCATTTCTCCAGGC \\
\hline SPA1-133Thr(A) & $121994-122013$ [Ex4] & TGCAGGGCTCCATAATGACA \\
\hline SPA1-133Thr(G) & 121994-122013 [Ex4] & TGCAGGGCTCCATAATGACG \\
\hline Consensus-133 & 122931-122911 [3,UTR] & TACCTGGCCTTCTAACCTCAT \\
\hline Consensus-219 & 121711-121732 [Intr3] & ATAGGAAAGCAAGTTCTCCACC \\
\hline SPA1-219Arg & $122288-122269$ [Ex4] & ACACACTGCTCTTTTCCCCG \\
\hline SPA1-219Trp & $122288-122269$ [Ex4] & ACACACTGCTCTTTTCCCCA \\
\hline SPA2-9Thr & $67686-67705[\mathrm{Ex} 1]$ & GGCTGCCATCAAGATGAGGT \\
\hline SPA2-9Asn & $67687-67705[\mathrm{Ex} 1]$ & GCTGCCATCAAGATGAGGG \\
\hline Consensus-9 & $67921-67900[$ Prom $]$ & GTGCCAGATGATGCTTGGAATT \\
\hline SPA2-91Ala & $67170-67154$ [Ex2] & TGGAGAGAAGGGGGAGG \\
\hline SPA2-91Pro & $67170-67154$ [Ex2] & TGGAGAGAAGGGGGAGC \\
\hline Consensus-91 & 66769-66788 [Intr2] & CCTGATCACACCATCTGCCT \\
\hline SPA2-140Ser(C) & $65802-65783$ [Ex4] & TAGGAGAGAAGGTCTTCTCC \\
\hline SPA2-140Ser(T) & $65803-65783[\mathrm{Ex} 4]$ & GTAGGAGAGAAGGTCTTCTCT \\
\hline SPA2-223Gln & $65516-65536[\mathrm{Ex} 4]$ & TGTGTACATCTCCACACACTG \\
\hline SPA2-223Lys & $65515-65536[\mathrm{Ex} 4]$ & CTGTGTACATCTCCACACACTT \\
\hline Consensus-140 & $65407-65427[\mathrm{Ex} 4]$ & AAACTGAAGGCCAGACAGGAT \\
\hline Consensus-223 & $66104-66083$ [Intr3] & AAGAAAGCAAGTTCTCTGCCTG \\
\hline SPD-11Thr & $84844-84823$ [Ex1] & AGACCTACTCCCACAGAACAAT \\
\hline SPD-11Met & $84844-84823$ [Ex1] & ACCTACTCCCACAGAACAAC \\
\hline Consensus-D11 & $84644-84664$ [Intr1] & AGAGTTGCTGGGCTAGTTACA \\
\hline SPD-160Thr & 80239-80221 [Ex4] & CGTGGAGTCCCTGGAAACA \\
\hline SPD-160Ala & 80239-80221 [Ex4] & GTGGAGTCCCTGGAAACG \\
\hline Consensus-D160 & $79662-79682$ [Ex5] & САСТTTCTCССТTTGCTCСТT \\
\hline
\end{tabular}

Ex, Exon; Intr, Intron; Prom, Promotor (modified from Pantelidis et al. 2003)

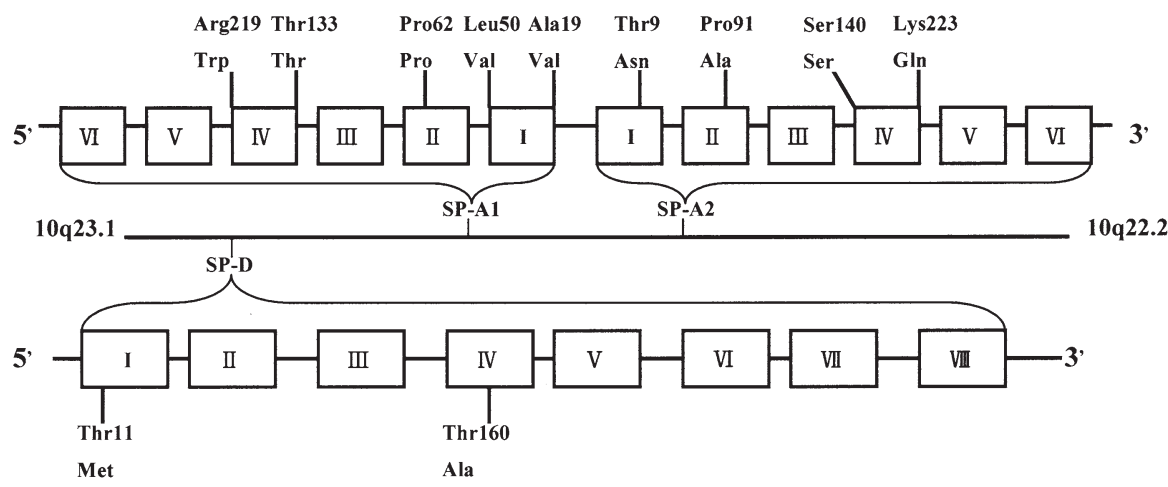

Fig. 1. Structural organization of the human SP-A and SP-D genes. These genes are located on the long arm of chromosome 10 at 10q22.2-23.1. SP-A1 and SP-A2 genes are found in opposite transcriptional orientation. Boxes represent the exonic regions. SP-A1 and -A2 genes have six exons, while SP-D has eight exons. All the SNP sites we studied are in the exonic regions (modified from Kishore et al. 2006). 
Table 2. Genotype and allele frequencies of SP-A, SP-D genes.

\begin{tabular}{|c|c|c|c|c|c|c|c|}
\hline \multirow{2}{*}{ Genotype } & \multicolumn{3}{|c|}{ Group } & \multirow{2}{*}{ Allele } & \multicolumn{3}{|c|}{ Group } \\
\hline & contols & $\mathrm{r}-\mathrm{UTI}$ & $P$ & & contols & r-UTI & $P$ \\
\hline \multicolumn{8}{|l|}{ SP-A1 } \\
\hline \multicolumn{8}{|l|}{ Ala19Val } \\
\hline $\mathrm{Val} / \mathrm{Val}$ & $15(50.0)$ & $6(18.8)$ & $0.033^{*}$ & Val & $41(68.3)$ & $32(50.0)$ & $0.038 *$ \\
\hline $\mathrm{Ala} / \mathrm{Val}$ & 11(36.7) & $20(62.4)$ & & & & & \\
\hline Ala/Ala & $4(13.3)$ & $6(18.8)$ & & Ala & 19(31.7) & $32(50.0)$ & \\
\hline \multicolumn{8}{|l|}{ Leu50Val } \\
\hline Leu/Leu & $4(13.3)$ & $3(9.4)$ & 0.616 & Leu & $17(28.3)$ & $13(20.3)$ & 0.297 \\
\hline Leu/Val & $9(30.0)$ & $7(21.9)$ & & & & & \\
\hline $\mathrm{Val} / \mathrm{Val}$ & $17(56.7)$ & $22(68.8)$ & & Val & $43(71.7)$ & $51(79.7)$ & \\
\hline \multicolumn{8}{|l|}{ Pro62Pro } \\
\hline Pro/Pro(AA) & $16(13.3)$ & $21(65.6)$ & 0.557 & Pro(A) & $41(68.3)$ & $50(78.1)$ & 0.218 \\
\hline Pro/Pro(AG) & $9(30.0)$ & $8(25.0)$ & & & & & \\
\hline Pro/Pro(GG) & $5(56.7)$ & $3(9.4)$ & & Pro(G) & $19(31.7)$ & $14(21.9)$ & \\
\hline \multicolumn{8}{|l|}{ Thr133Thr } \\
\hline Thr/Thr(AA) & $23(76.7)$ & $27(84.4)$ & 0.701 & $\operatorname{Thr}(\mathrm{A})$ & $51(85.0)$ & $58(90.6)$ & 0.337 \\
\hline Thr/Thr(AG) & $5(16.7)$ & $4(12.5)$ & & & & & \\
\hline Thr/Thr(GG) & $2(6.6)$ & $1(3.1)$ & & $\operatorname{Thr}(\mathrm{G})$ & $9(15.0)$ & $6(9.4)$ & \\
\hline \multicolumn{8}{|l|}{ Arg219Trp } \\
\hline Arg/Arg & $18(60.0)$ & $16(50.0)$ & 0.575 & Arg & $45(75.0)$ & $42(65.6)$ & 0.254 \\
\hline Arg/Trp & $9(30.0)$ & $10(31.2)$ & & & & & \\
\hline $\operatorname{Trp} / \operatorname{Trp}$ & $3(10.0)$ & $6(18.8)$ & & $\operatorname{Trp}$ & $15(25.0)$ & $22(34.4)$ & \\
\hline \multicolumn{8}{|l|}{ SP-A2 } \\
\hline \multicolumn{8}{|l|}{ Thr9Asn } \\
\hline Asn/Asn & $4(13.4)$ & $4(12.5)$ & 0.567 & Asn & $21(35.0)$ & $26(40.6)$ & 0.519 \\
\hline Thr/Asn & $13(43.3)$ & $18(56.3)$ & & & & & \\
\hline Thr/ Thr & $13(43.3)$ & $10(31.2)$ & & Thr & $39(65.0)$ & $38(59.4)$ & \\
\hline \multicolumn{8}{|l|}{ Pro91Ala } \\
\hline Pro/Pro & $6(20.0)$ & $2(6.3)$ & 0.27 & Pro & $22(36.7)$ & $17(26.6)$ & 0.226 \\
\hline Pro/Ala & $10(33.3)$ & 13(40.6) & & & & & \\
\hline Ala/Ala & $14(46.7)$ & $17(53.1)$ & & Ala & $38(63.3)$ & $47(73.4)$ & \\
\hline \multicolumn{8}{|l|}{ Ser140Ser } \\
\hline $\operatorname{Ser} / \operatorname{Ser}(\mathrm{CC})$ & $17(56.7)$ & $20(62.5)$ & 0.638 & $\operatorname{Ser}(\mathrm{C})$ & $43(71.7)$ & $50(78.1)$ & 0.407 \\
\hline $\operatorname{Ser} / \operatorname{Ser}(\mathrm{CT})$ & $9(30.0)$ & $10(31.3)$ & & & & & \\
\hline Ser/Ser(TT) & $4(13.3)$ & $2(6.2)$ & & $\operatorname{Ser}(\mathrm{T})$ & $17(28.3)$ & $14(21.9)$ & \\
\hline \multicolumn{8}{|l|}{ Lys223Gln } \\
\hline Gln/Gln & 11(36.7) & $22(68.8)$ & $0.041^{*}$ & Gln & $35(58.3)$ & 51(79.9) & $0.012 *$ \\
\hline Lys/Gln & $13(43.3)$ & $7(21.9)$ & & & & & \\
\hline Lys/Lys & $6(20.0)$ & $3(9.3)$ & & Lys & $25(41.7)$ & $13(20.3)$ & \\
\hline \multicolumn{8}{|l|}{ SP-D } \\
\hline \multicolumn{8}{|l|}{ Thr11Met } \\
\hline Met/Met & 11(36.7) & $9(28.1)$ & 0.771 & Met & $37(61.7)$ & $36(56.2)$ & 0.54 \\
\hline Thr/Met & $15(50.0)$ & $18(56.3)$ & & & & & \\
\hline Thr/Thr & $4(13.3)$ & $5(15.6)$ & & Thr & $23(38.3)$ & $28(43.8)$ & \\
\hline \multicolumn{8}{|l|}{ Thr160Ala } \\
\hline Thr/Thr & $3(10.0)$ & $6(18.8)$ & 0.574 & Thr & $16(26.7)$ & $23(35.9)$ & 0.267 \\
\hline Thr/Ala & $10(33.3)$ & 11(34.4) & & & & & \\
\hline Ala/Ala & $17(56.7)$ & $15(46.9)$ & & Ala & $44(73.3)$ & $41(64.4)$ & \\
\hline
\end{tabular}

r-UTI, Recurrent urinary tract infection; $* p<0.05$ considered as statistically significant. 
hematuria and one had fever. The average course of disease was $4.00 \pm 3.67$ years.

\section{Association between SP-A and SP-D polymorphisms and $r$-UTI}

Analysis of SP-A and SP-D polymorphism demonstrated that all studied loci had three genotypes, two homozygotes and one heterozygote. All the genotype and allele frequency distributions were in line with Hardy-Weinberg equilibrium. In comparison to the controls, the r-UTI patient group showed no significant difference in terms of allele and genotype frequencies in either Leu50Val, Pro62Pro, Thr133Thr, Arg219Trp SNP of SP-A1 gene, Thr9Asn, Pro91Ala, Ser140Ser SNP of SP-A2 gene or Thr11Met, Thr160Ala SNP of SP-D gene $(p>0.05)$. However, the genotype and allele frequencies of Ala19Val polymorphisms of SP-A1 gene (Ala/Ala genotype: $p=$ 0.033; Ala allele: $p=0.038$ ) and Lys223Gln polymorphisms of SP-A2 gene (Gln/Gln genotype: $p=0.041$; Gln allele: $p=0.012$ ) were significantly different in r-UTI patients in comparison with healthy controls (Table 2 and Fig. 2). The results indicated that our subjects with the 19Ala/Ala or $223 \mathrm{Gln} / \mathrm{Gln}$ genotype were more susceptible to r-UTI.

Serum and urine SP-A and SP-D protein levels in $r-U T I$ and healthy control groups

The urine and serum SP-A and SP-D protein levels in $r$-UTI patients and healthy control subjects were shown in Table 3 and Table 4. When compared with healthy controls, serum SP-A and SP-D proteins were significantly higher in r-UTI patients (SP-A, $p=0.001$; SP-D, $p=0.001$ ), whereas urinary SP-A and SP-D proteins were significantly lower in r-UTI patients (SP-A, $p=0.001$; SP-D, $p=0.012$ ).

Correlation between serum and urine SP-A protein levels and SP-A genotypes in $r$-UTI patients

r-UTI patients with 19Ala/Ala $(p=0.001)$ or $223 \mathrm{Gln} /$ Gln $(p=0.003)$ genotype had significantly higher serum SP-A protein levels than those with 19ValVal/AlaVal or 223GlnLys/LysLys genotypes, respectively. In contrast, r-UTI patients with $19 \mathrm{Ala} / \mathrm{Ala}(p=0.001)$ or $223 \mathrm{Gln} / \mathrm{Gln}$ $(p=0.006)$ genotype showed significantly lower urinary SP-A level than those with 19ValVal/AlaVal or 223GlnLys/ LysLys genotypes, separately. (Fig. 3)

\section{Discussion}

The present study investigated the association between SNP of SP-A1, SP-A2 and SP-D genes and r-UTI in Chinese. A total of 11 variable loci (five of SP-A1, four of SP-A2 and two of SP-D) were observed in subjects. Of these 11 SNP, two SNP i.e. Ala19Val of SP-A1 and Lys223Gln of SP-A2 were associated with susceptibility to r-UTI. Subjects with 19Ala/Ala or 223Gln/Gln genotype appeared with high serum and low urine SP-A levels.

All the subjects recruited for the current study were of the same ethnic groups and lived in the similar environ- ments to avoid potential problems caused by genetic differ-

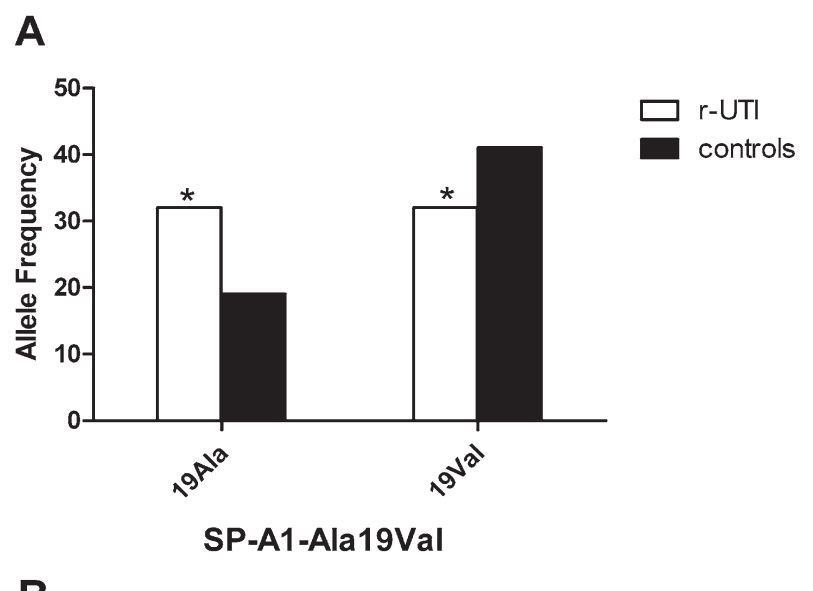

B

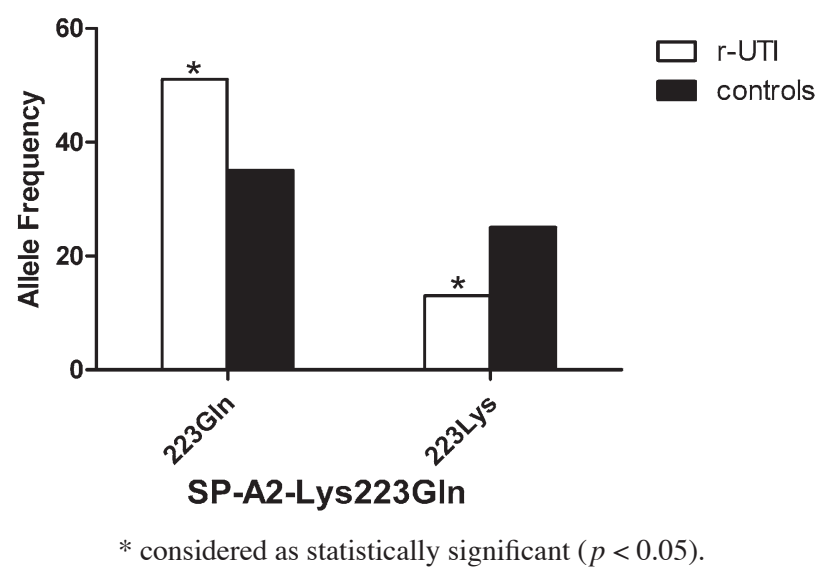

Fig. 2. Comparison of allele frequencies in r-UTI patients and healthy controls. The frequencies of 19Ala allele of SP-A1 (A) and 223Gln allele of SP-A2 (B) in r-UTI patients were significantly higher than those in control subjects $(p<0.05)$.

ences and external factors. The allele frequency distributions of the current study were different from those of previous studies (Löfgren et al. 2002; Saxena et al. 2005). In our study, the 19Ala allele was found with frequencies of $50.0 \%$ in r-UTI patients and $31.7 \%$ in controls in Chinese population, while the $223 \mathrm{Gln}$ allele was observed with frequencies of $79.9 \%$ in r-UTI patients and $58.3 \%$ in controls. However, the frequencies of 19Ala allele were $36.4 \%$ in high-altitude pulmonary edema patients and $8.3 \%$ in controls in Indian population (Saxena et al. 2005). The frequencies of $223 \mathrm{Gln}$ allele were $27.9 \%$ in respiratory syncytial virus infection patients and $17.9 \%$ in controls in Finland population (Löfgren et al. 2002). The possible reason of allele distribution discrepancies between our and previous studies may be due to the different races, different characteristics among individual subjects, such as age, occupation as well as living environment.

The Lys223Gln variant was observed to contribute to occurrence of several kinds of infective diseases. For 
Table 3. The Serum and Urine SP-A protein levels in r-UTI and healthy controls.

\begin{tabular}{cccccc}
\hline Group & Number & Serum SP-A $(\mathrm{pmol} / \mathrm{mL})$ & $P$ & Urine SP-A $(\mathrm{pmol} / \mathrm{mL})$ & $P$ \\
\hline r-UTI & 32 & $170.490 \pm 100.226$ & $0.001^{*}$ & $45.586 \pm 4.410$ & $0.001^{*}$ \\
controls & 30 & $80.983 \pm 19.634$ & & $106.614 \pm 72.772$ & \\
\hline
\end{tabular}

r-UTI, Recurrent urinary tract infection; SP-A, Surfactant protein A; ${ }^{*} p<0.05$ considered as statistically significant.

Table 4. The Serum and Urine SP-D protein levels in r-UTI and healthy controls.

\begin{tabular}{cccccc}
\hline Group & Number & Serum SP-D $(\mathrm{pmol} / \mathrm{mL})$ & $P$ & Urine SP-D $(\mathrm{pmol} / \mathrm{mL})$ & $P$ \\
\hline r-UTI & 32 & $135.476 \pm 96.448$ & $0.001^{*}$ & $33.618 \pm 3.678$ & $0.012^{*}$ \\
controls & 30 & $64.089 \pm 11.346$ & & $59.112 \pm 45.585$ & \\
\hline
\end{tabular}

r-UTI, Recurrent urinary tract infection; SP-A, Surfactant protein A; ${ }^{*} p<0.05$ considered as statistically significant.

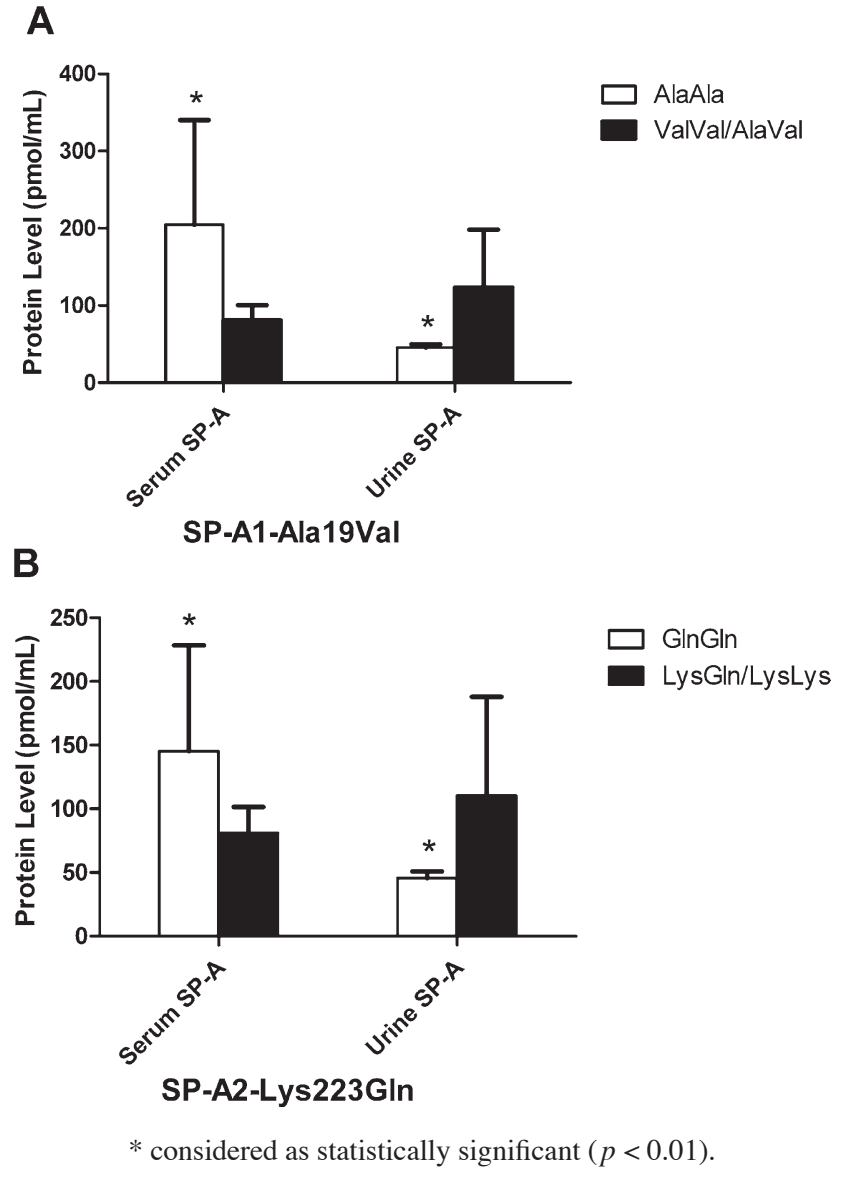

Fig. 3. Correlation between SP-A genotype and SP-A protein levels in serum and urine. r-UTI patients with 19Ala/Ala (A) or $223 \mathrm{Gln} / \mathrm{Gln}$ (B) genotype showed higher serum and lower urine SP-A protein levels than those with $19 \mathrm{ValVal} / \mathrm{AlaVal}$ or $223 \mathrm{GlnLys} / \mathrm{LysLys}$ genotypes, respectively. $(p<0.01)$.

example, 223Lys allele of SP-A2 was associated with susceptibility to RSV infection in infant of Finland (Löfgren et al. 2002). England patients with 223Lys allele showed to increase affectability to meningococcal disease after neisse- ria meningitides infection (Jack et al. 2006). It was also found that 223Lys allele mutation acted as a risk factor to increase the sensitivity to Aspergillus-mediated allergy in North Indian population (Saxena et al. 2003). In contrast, we demonstrated that $223 \mathrm{Gln}$ allele may be a useful biomarker to predict susceptibility to r-UTI in Chinese women $(p<0.05)$. In addition, two SNPs (Thr11Met and Thr160Ala) of SP-D were investigated, but no significant difference in frequencies of alleles and genotypes were observed between r-UTI and health controls in the present study. However, Thr11Met polymorphism has been suggested to increase susceptibility to several infective diseases (Lahti et al. 2002; Hartshorn et al. 2007). The different impact of SP-A and SP-D variants related with ethnic background or main characteristics of the individuals.

SNP of Ala19Val in SP-A1 and Lys223Gln in SP-A2 are located in the exons of SP-A. Change from 19Val allele to 19Ala allele alters amino acid residue from Valine (GTG) to Alanine (GG) ; similarly, the 223Lys to 223Gln transversion results in a change from Lysine ( $\underline{A} A G)$ to Glutamine (CAG). These amino acid changes of SP-A1 and SP-A2 would have an influence on SP-A structure, expression and function. Recent in vitro studies suggested that $223 \mathrm{Gln}$ allele and 19Ala allele variants possessed greater biological activity than 223Lys allele and 19Val allele variants. SP-A2 variants with $223 \mathrm{Gln}$ allele showed higher activity in inducing production of TNF-alpha by THP-1 cell line compared with those 223Lys allele variants (Wang et al. 2000). Moreover, the biologic activity of 19Ala allele variant inhibiting ATP-stimulated PC secretion from alveolar type II cells was higher than 19Val allele (Wang et al. 2004). Furthermore, 19Ala allele variant showed greater ability to stimulate phagocytosis of $P$. aeruginosa (Mikerov et al. 2007) and bind to bacterial Re-LPS (Sánchez-Barbero et al. 2007) when compared with 19 Val allele variant. Furthermore, different SP-A genotypes express different protein levels (Floros and Hoover 1998). In the present study, we observed that r-UTI patients with 19Ala/Ala or $223 \mathrm{Gln} / \mathrm{Gln}$ genotype are associated with higher level of serum SP-A and lower level of urinary SP-A. Therefore, 
we speculated the reasons that subjects with 19Ala/Ala or $223 \mathrm{Gln} / \mathrm{Gln}$ genotype were susceptible to r-UTI might be potentially due to the lower urinary SP-A expression and the weaker capacities to regulate host innate immunity and clean pathogens of their urinary tract.

In the present study, both serum SP-A and SP-D levels were increased, and urinary SP-A and SP-D were decreased in r-UTI patients $(p<0.05)$. The serum level has been suggested as a biomarker for interstitial lung disease (Asano et al. 2001). In the earlier observation, the bronchial alveolar lavage (BAL) fluid SP-A levels in idiopathic pulmonary fibrosis patients (IPF) were reduced (McCormack et al. 1995); however, a recent study showed that baseline serum SP-A levels were increased in IPF patients (Kinder et al. 2009). The postulated mechanisms for increased serum protein level may be related to high secretion and leakage from alveolar space to interstitium, and low clearance from the vascular compartment (Greene et al. 2002). It was indicated that the high serum protein level originated from low BAL fluid protein level. This may provide a similar mechanism that may be contributing to differences in serum and urinary SP-A and SP-D levels observed in the present study.

In summary, we have demonstrated that the Ala19Val polymorphism of SP-A1 gene and the Lys $223 \mathrm{Gln}$ polymorphism of SP-A2 gene may be one of the genetic factors that affect susceptibility to r-UTI in Chinese women, whereas the other polymorphisms showed no significant association with r-UTI. Although serum SP-A and SP-D levels were increased, urinary SP-A and SP-D levels were decreased in r-UTI patients. Interestingly, there was a significant correlation between 19Ala/Ala or $223 \mathrm{Gln} / \mathrm{Gln}$ genotype and SP-A protein levels in fluid. However, further studies will be needed to investigate why the Ala19Val and Lys223Gln polymorphism could alter r-UTI susceptibility.

\section{Acknowledgments}

This work was supported by a grant from the National Science Foundation Funds of China (30670985).

\section{References}

Asano, Y., Ihn, H., Yamane, K., Yazawa, N., Kubo, M., Fujimoto, M. \& Tamaki, K. (2001) Clinical significance of surfactant protein $\mathrm{D}$ as a serum marker for evaluating pulmonary fibrosis in patients with systemic sclerosis. Arthritis Rheum., 44, 1363-1369.

DiAngelo, S., Lin, Z., Wang, G., Phillips, S., Ramet, M., Luo, J. \& Floros, J. (1999) Novel, non-radioactive, simple and multiplex PCR-cRFLP methods for genotyping human SP-A and SP-D marker alleles. Dis. Markers, 15, 269-281.

Floros, J. \& Hoover, R.R. (1998) Genetics of the hydrophilic surfactant proteins A and D. Biochim. Biophys. Acta, 1408, 312-322.

Foxman, B. (1990) Recurring urinary tract infection: incidence and risk factors. Am. J. Public Health, 80, 331-333.

Greene, K.E., King, T.E. Jr., Kuroki, Y., Bucher-Bartelson, B., Hunninghake, G.W., Newman, L.S., Nagae, H. \& Mason, R.J. (2002) Serum surfactant proteins-A and -D as biomarkers in idiopathic pulmonary fibrosis. Eur. Respir. J., 19, 439-446.

Hartshorn, K.L., White, M.R., Tecle, T., Tornoe, I., Sorensen, G.L.,
Crouch, E.C. \& Holmskov, U. (2007) Reduced influenza viral neutralizing activity of natural human trimers of surfactant protein D. Respir. Res., 8, 9.

Hawn, T.R., Scholes, D., Li, S.S., Wang, H., Yang, Y., Roberts, P.L., Stapleton, A.E., Janer, M., Aderem, A., Stamm, W.E., Zhao, L.P. \& Hooton, T.M. (2009) Toll-like receptor polymorphisms and susceptibility to urinary tract infections in adult women. PLos. One., 4, e5990.

Jack, D.L., Cole, J., Naylor, S.C., Borrow, R., Kaczmarski, E.B., Klein, N.J. \& Read, R.C. (2006) Genetic polymorphism of the binding domain of surfactant protein-A2 increases susceptibility to meningococcal disease. Clin. Infect. Dis., 43, 1426-1433.

Karinch, A.M., deMello, D.E. \& Floros, J. (1997) Effect of genotype on the levels of surfactant protein-A mRNA and on the SP-A2 splice variants in adult humans. Biochem. J., 321, 39-47.

Karoly, E., Fekete, A., Banki, N.F., Szebeni, B., Vannay, A., Szabo, A.J., Tulassay, T. \& Reusz, G.S. (2007) Heat shock protein 72 (HSPA1B) gene polymorphism and Toll-like receptor (TLR) 4 mutation are associated with increased risk of urinary tract infection in children. Pediatr. Res., 61, 371-374.

Kinder, B.W., Brown, K.K., McCormack, F.X., Ix, J.H., Kervitsky, A., Schwarz, M.I. \& King, T.E. Jr. (2009) Serum surfactant protein-A is a strong predictor of early mortality in Idiopathic Pulmonary Fibrosis. Chest, 135, 1557-1563.

King, R.J. \& Clements, J.A. (1972) Surface active materials from dog lung. I. Method of isolation. Am. J. Physiol., 223, 707714.

Kishore, U., Greenhough, T.J., Waters, P., Shrive, A.K., Ghai, R., Kamran, M.F., Bernal, A.L., Reid, K.B., Madan, T. \& Chakraborty T. (2006) Surfactant proteins SP-A and SP-D: structure, function and receptors. Mol. Immunol., 43, 12931315.

Kölble, K., Lu, J., Mole, S.E., Kaluz, S. \& Reid, K.B. (1993) Assignment of the human pulmonary surfactant protein D gene to $10 \mathrm{q} 22-\mathrm{q} 23$ close to the surfactant protein A gene cluster. Genomics, 17, 294-298.

Lahti, M., Lofgren, J., Marttila, R., Renko, M., Klaavuniemi, T., Haataja, R., Ramet, M. \& Hallman, M. (2002) Surfactant protein $\mathrm{D}$ gene polymorphism associated with severe respiratory syncytial virus infection. Pediatr. Res., 51, 696-699.

LeVine, A.M., Whitsett, J.A., Gwozdz, J.A., Richardson, T.R., Fisher, J.H., Burhans, M.S. \& Korfhagen, T.R. (2000) Distinct effects of surfactant protein A or D deficiency during bacterial infection on the lung. J. Immunol., 165, 3934-3940.

Linke, M.J., Harris, C.E., Korfhagen, T.R., McCormack, F.X., Ashbaugh, A.D., Steele, P., Whitsett, J.A. \& Walzer, P.D. (2001) Immunosuppressed surfactant protein A-deficient mice have increased susceptibility to Pneumocystis carinii infection. $J$. Infect. Dis., 183, 943-952.

Löfgren, J., Rämet, M., Renko, M., Marttila, R. \& Hallman, M. (2002) Association between surfactant protein A gene locus and severe respiratory syncytial virus infection in infants. $J$. Infect. Dis., 185, 283-289.

Lundstedt, A.C., McCarthy, S., Gustafsson, M.C., Godaly, G., Jodal, U., Karpman, D., Leijonhufvud, I., Lindén, C., Martinell, J., Ragnarsdottir, B., Samuelsson, M., Truedsson, L., Andersson, B. \& Svanborg, C. (2007) A genetic basis of susceptibility to acute pyelonephritis. PLoS. One., 2, e825.

Mabeck, C.E. (1972) Treatment of uncomplicated urinary tract infection in non-pregnant women. Postgrad. Med. J., 48 , 69-75.

McCormack, F.X., King, T.E. Jr., Bucher, B.L., Nielsen, L. \& Mason, R.J. (1995) Surfactant protein A predicts survival in idiopathic pulmonary fibrosis. Am. J. Respir. Crit. Care Med., 152, 751-759.

Mikerov, A.N., Wang, G., Umstead, T.M., Zacharatos, M., Thomas, N.J., Phelps, D.S. \& Floros, J. (2007) Surfactant protein A2 
(SP-A2) variants expressed in $\mathrm{CHO}$ cells stimulate phagocytosis of pseudomonas aeruginosa more than do SP-A1 variants. Infect. Immun., 75, 1403-1412.

Pantelidis, P., Lagan, A.L., Davies, J.C., Welsh, K.I. \& du Bois, R.M. (2003) A single round PCR method for genotyping human surfactant protein (SP)-A1, SP-A2 and SP-D gene alleles. Tissue Antigens, 61, 317-321.

Saxena, S., Kumar, R., Madan, T., Gupta, V., Muralidhar, K. \& Sarma, P.U. (2005) Association of polymorphisms in pulmonary surfactant protein $\mathrm{A} 1$ and $\mathrm{A} 2$ genes with high-altitude pulmonary edema. Chest, 128, 1611-1619.

Saxena, S., Madan, T., Shah, A., Muralidhar, K. \& Sarma, P.U. (2003) Association of polymorphisms in the collagen region of SP-A2 with increased levels of total IgE antibodies and eosinophilia in patients with allergic bronchopulmonary aspergillosis. J. Allergy Clin. Immunol., 111, 1001-1007.

Sánchez-Barbero, F., Rivas, G., Steinhilber, W. \& Casals, C. (2007) Structural and functional differences among human surfactant proteins SP-A1, SP-A2 and co-expressed SP-A1/ SP-A2: role of supratrimeric oligomerization. Biochem. J., 406, 479-489.

Tabel, Y., Berdeli, A. \& Mir, S. (2007) Association of TLR2 gene Arg753Gln polymorphism with urinary tract infection in children. Int. J. Immunogenet., 34, 399-405.

Thomas, N.J., DiAngelo, S., Hess, J.C., Fan, R., Ball, M.W., Geskey, J.M., Willson, D.F. \& Floros, J. (2009) Transmission of surfactant protein variants and haplotypes in children hospitalized with respiratory syncytial virus. Pediatr. Res., 66, 70-73.

Tian, S., Ding, G., Wang, G. \& Gui, Y. (2005) Expression of surfactant protein $\mathrm{A}$ in the rat kidney with acute pyelonephritis. Chinese Journal of Nephrology, 8, 469-472.

Vaid, M., Kaur, S., Sambatakou, H., Madan, T., Denning, D.W. \& Sarma, P.U. (2007) Distinct alleles of mannose-binding lectin (MBL) and surfactant proteins A (SP-A) in patients with chronic cavitary pulmonary aspergillosis and allergic bronchopulmonary aspergillosis. Clin. Chem. Lab. Med., 45, 183-186.

Walker, S.R., Williams, M.C. \& Benson, B. (1986) Immunocytochemical localization of the major surfactant apoproteins in type II cells, Clara cells, and alveolar macrophages of rat lungs. J. Histochem. Cytochem., 34, 1137-1148.

Wang, G., Bates-Kenney, S.R., Tao, J.Q., Phelps, D.S. \& Floros, J. (2004) Differences in biochemical properties and in biological function between human SP-A1 and SP-A2 variants, and the impact of ozone-induced oxidation. Biochemistry, 43, 42274239.

Wang, G., Phelps, D.S., Umstead, T.M. \& Floros, J. (2000) Human SP-A protein variants derived from one or both genes stimulate TNF- $\alpha$ production in the THP-1 cell line. Am. J. Physiol. Lung Cell. Mol. Physiol., 278, L946-L954. 